\title{
Article \\ Biochemical and Behavioral Consequences of Ethanol Intake in a Mouse Model of Metabolic Syndrome
}

\author{
Pablo Baliño ${ }^{\dagger}$, Ricard Romero-Cano ${ }^{\dagger}\left[\right.$ and María Muriach ${ }^{*}$ \\ Unitat Predepartamental de Medicina, Universitat Jaume I, 12071 Castelló de la Plana, Spain; balino@uji.es (P.B.); \\ romeror@uji.es (R.R.-C.) \\ * Correspondence: muriach@uji.es \\ † Authors contributed equally to this work.
}

Citation: Baliño, P.; Romero-Cano,

R.; Muriach, M. Biochemical and

Behavioral Consequences of Ethanol Intake in a Mouse Model of Metabolic Syndrome. Int. J. Mol. Sci. 2021, 22, 807. https://doi.org/10.3390/ ijms22020807

Received: 16 December 2020 Accepted: 8 January 2021 Published: 15 January 2021

Publisher's Note: MDPI stays neutral with regard to jurisdictional clai$\mathrm{ms}$ in published maps and institutional affiliations.

Copyright: (C) 2021 by the authors. Licensee MDPI, Basel, Switzerland. This article is an open access article distributed under the terms and conditions of the Creative Commons Attribution (CC BY) license (https:// creativecommons.org/licenses/by/ $4.0 /)$.

\begin{abstract}
Ethanol abuse is a common issue in individuals with sedentary lifestyles, unbalanced diets, and metabolic syndrome. Both ethanol abuse and metabolic syndrome have negative impacts on the central nervous system, with effects including cognitive impairment and brain oxidative status deterioration. The combined effects of ethanol abuse and metabolic syndrome at a central level have not yet been elucidated in detail. Thus, this work aims to determine the effects of ethanol intake on a mouse model of metabolic syndrome at the behavioral and biochemical levels. Seven-week-old male control (B6.V-Lep ob/+JRj) and leptin-deficient (metabolic syndrome) (B6.V-Lep ob/obJRj) mice were used in the study. Animals were divided into four groups: control, ethanol, obese, and obese-ethanol. Ethanol consumption was monitored for 6 weeks. Basal glycemia, insulin, and glucose overload tests were performed. To assess short- and long-term memory, an object recognition test was used. In order to assess oxidative status in mouse brain samples, antioxidant enzyme activity was analyzed with regard to glutathione peroxidase, glutathione reductase, glutathione, glutathione disulfide, lipid peroxidation products, and malondialdehyde. Ethanol intake modulated the insulin response and impaired the oxidative status in the ob mouse brain.
\end{abstract}

Keywords: ethanol; diabetes; metabolic syndrome; oxidative stress; mice

\section{Introduction}

According to the latest World Health Organization report on ethanol and health, more than 2.3 billion people are heavy ethanol consumers. Ethanol abuse has high social economic costs due to its elevated mortality and morbidity. In the European region alone, ethanol consumption is responsible for $10 \%$ of total deaths every year [1].

Ethanol abuse is related to obesity and an increased risk of metabolic syndrome (MS) and type 2 diabetes mellitus (T2D) [2]. MS occurs when different metabolic risk factors such as dyslipidemia, arterial hypertension, obesity, insulin resistance, and hyperinsulinism converge [3]. MS-elicited insulin resistance leads to impaired glucose homeostasis, which has been defined as a key mechanism involved in the pathogenesis of T2D [2,4-7]. Moreover, several factors such as diet, lifestyle, physical activity, mental health, and ethanol abuse interact with regard to the risk of suffering both pathologies [8-10]. In this respect, it has been demonstrated that high levels of ethanol consumption play a critical role in developing insulin resistance [11]. In fact, the World Health Organization has considered T2D to be a complication of ethanol abuse [1].

Chronic ethanol consumption threatens the oxidative defense of the organism and promotes the activation of different inflammatory processes which are related to the onset of MS [12], neurodegenerative damage [13,14], and beta cell death through activation of reactive oxygen species (ROS) $[15,16]$. Interestingly, some authors have described a paradoxical effect, and demonstrated how moderate ethanol consumption can modulate and improve insulin response in T2D [17,18]. Schaller and coworkers studied the effect of high ethanol consumption in T2D patients and observed an increase in the insulin response 
which modulates T2D [19-28]. One of the molecular mechanisms involves an ethanoldependent increase in cAMP intracellular levels through a $\mathrm{Ca}^{2+}$-dependent mechanism. The intracellular calcium release elicited by ethanol thus boosts cellular insulin levels $[29,30]$. However, the mechanisms underlying the connection between T2D, MS, and ethanol abuse remain to be fully clarified.

On the other hand, it is widely known that ethanol metabolism is related to ROS production and mitochondrial injury, which are common features of acute and chronic ethanol exposure [31,32]. Via the dehydrogenase and microsomal ethanol oxidizing system, this ethanol-oxidative process generates $\mathrm{NADH}$ or $\mathrm{NADP}^{+}$. There is a subsequent increase in ROS levels, with the resultant oxidative stress representing an important threat to the oxidative system of the cell. Oxidative stress is also strongly correlated with prevalence of T2D and oxidative stress-induced tissue damage. Levels of different biomarkers such as 4-hydroxy-2-nonenal and malondialdehyde (MDA) as well as DNA base oxidation have been reported to be increased in the pancreatic tissue, plasma, and serum of T2D patients [32,33]. Moreover, it has been proven that the total antioxidant cellular defense is significantly diminished in T2D due to reduced levels of antioxidant metabolites such as catalase, superoxide dismutase, and the glutathione system, or nonenzymatic components such as vitamins $C$ and $E[32,34,35]$.

In this work, we aimed to evaluate the effect of chronic ethanol administration on a mouse model of MS, with a special focus on oxidative balance. Of the various animal models available for the study of MS, leptin-deficient mice (B6.Cg-Lep ${ }^{\mathrm{Ob}}$ ) were chosen. These are known as ob mice and are homozygous for the leptin mutation, exhibiting obesity, hyperphagia, transient hyperglycemia, glucose intolerance, and elevated plasma insulin.

The effects of chronic ethanol administration on the central nervous system were determined through an object recognition test to ascertain cognitive impairment with regard to short- and long-term memory. The presence of cellular oxidative injury was determined using a battery of oxidative status parameters including the antioxidants glutathione reductase (GR), glutathione peroxidase (GPx), glutathione (GSH), glutathione disulfide (GSSG), and L-cysteine. Malondialdehyde (MDA) was used as a measure to study lipid peroxidation damage to macromolecules.

\section{Results}

2.1. Effects of Ethanol Intake with Regard to Weight, Glucose Overdose, Insulin, and Basal Glycemia

In order to monitor weight changes elicited by chronic ethanol consumption, we monitored the weights of the mice over the course of the experiment. A two-way ANOVA showed significant differences between the wild-type (C, E) and MS groups (Ob, Ob-E) $(p<0.05$, Figure 1a).

Glycemic status was monitored weekly. Significant differences were found by a twoway ANOVA between the wild-type (C, E) and MS mice groups (Ob, Ob-E) in week 1. The Ob-E group presented significantly reduced glycemia values when compared to the Ob control group from weeks 2-6 ( $p<0.05$, Figure $1 b)$.

One-way ANOVA yielded significant differences in blood insulin concentrations between the wild-type (C, E) and MS mice groups (Ob, Ob-E) groups $(p<0.05$, Figure $1 \mathrm{c})$, with greater insulinemia found in the $\mathrm{Ob}$ and $\mathrm{Ob}-\mathrm{E}$ groups.

Figure $1 \mathrm{~d}$ depicts increased blood glucose levels (\% t0) at 30, 60, and $120 \mathrm{~min}$ with respect to basal glycemia (time $0 \mathrm{~min}$ ) over the course of the glucose overload test. A twoway ANOVA showed significant differences between the MS (Ob and $\mathrm{Ob}-\mathrm{E})$ and wild-type ( $\mathrm{C}$ and $\mathrm{E}$ ) mouse groups (Figure $1 \mathrm{~d},{ }^{*} p<0.05$ ). Thus, the Ob group presented greater increases in blood glucose levels as compared to the $\mathrm{C}$ and $\mathrm{E}$ groups. Moreover, the $\mathrm{Ob}-\mathrm{E}$ group showed the greatest increases in blood glucose levels at 30, 60, and $120 \mathrm{~min}$ after glucose administration. These were significantly different when compared to the $\mathrm{C}, \mathrm{E}$, and $\mathrm{Ob}$ groups (Figure $1 \mathrm{~d},{ }^{* *} p<0.05$ ). 


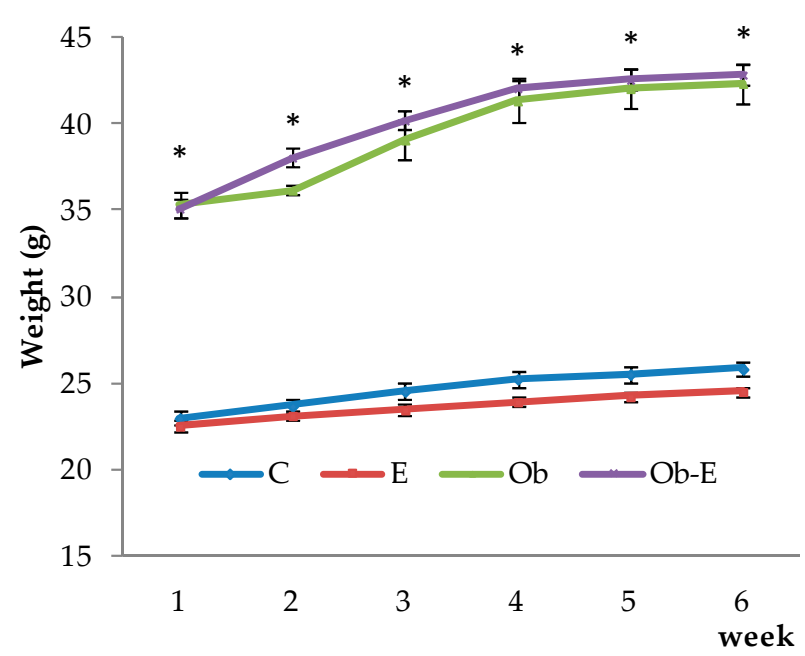

(a)

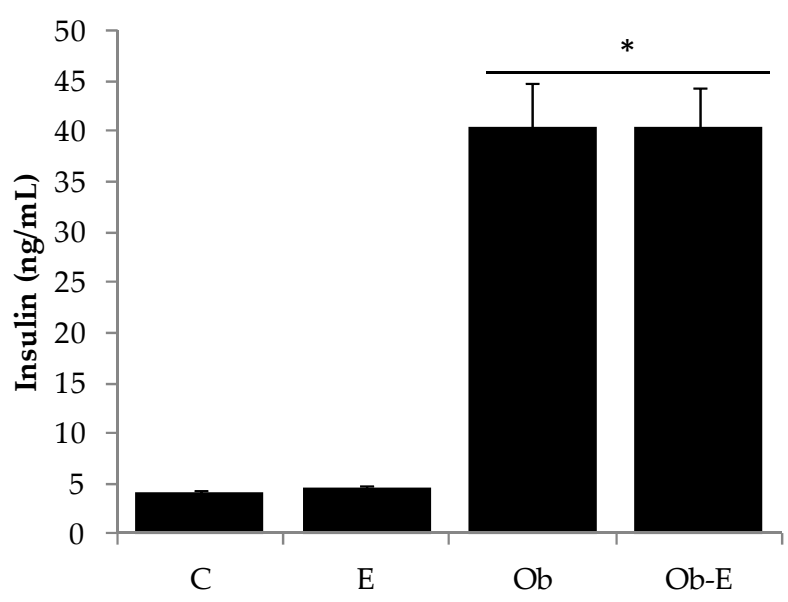

(c)

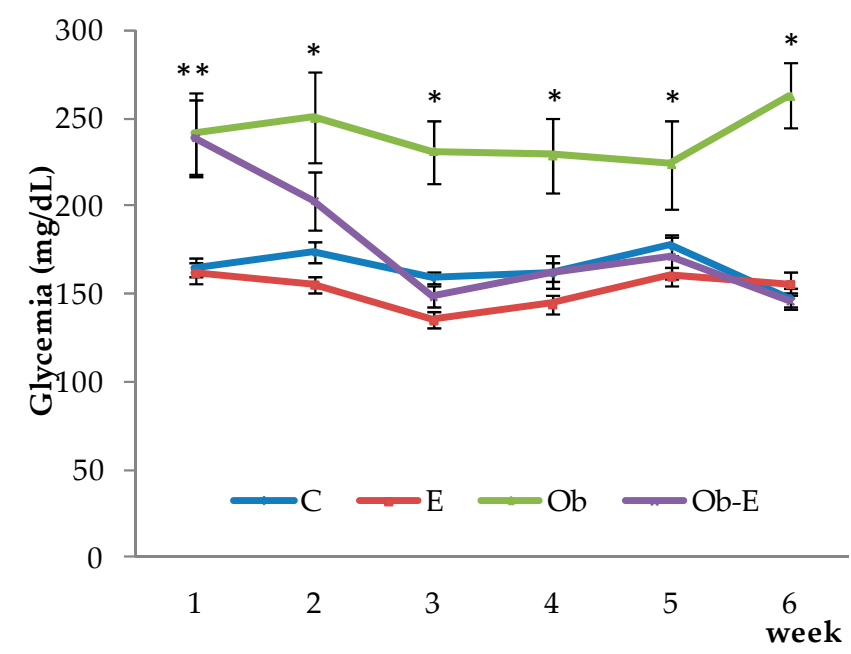

(b)

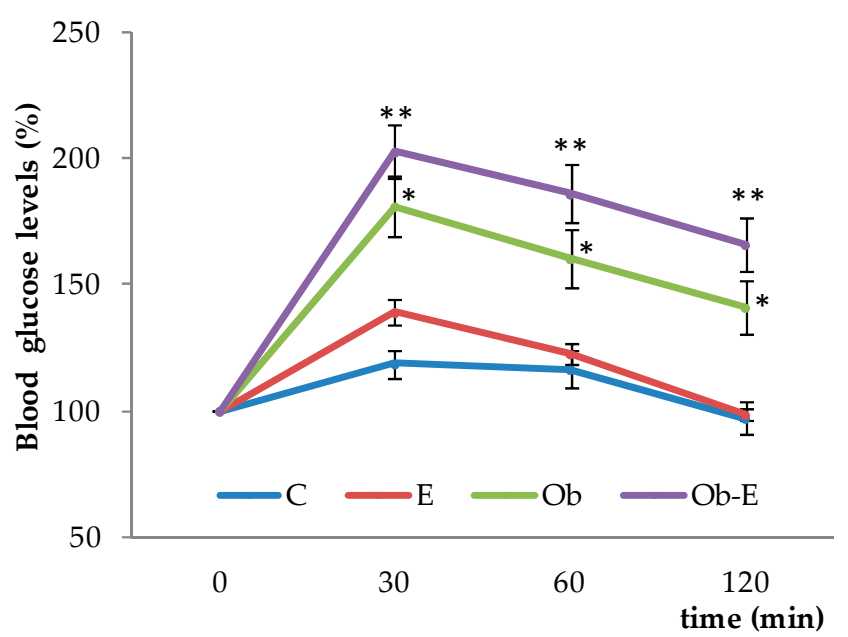

(d)

Figure 1. (a) Weekly animal weights $\left({ }^{*} p<0.05 \mathrm{Ob}-\mathrm{E}\right.$ and $\mathrm{Ob}$ vs. $\mathrm{C}$ and $\left.\mathrm{E}\right)$; (b) weekly basal glycemia $\left({ }^{*} p<0.05\right.$ vs. rest of groups, ${ }^{* *} p<0.05$ vs. C and E); (c) blood insulin levels ( ${ }^{*} p<0.05$ vs. $\mathrm{C}$ and $\mathrm{E}$ ); (d) blood glucose levels during the glucose overload test (\%) (** $p<0.05$ vs. all groups, ${ }^{*} p<0.05 \mathrm{Ob}$ vs. $\mathrm{C}$ and $\left.\mathrm{E}\right)$. C, wild-type control; E, wild-type ethanol; $\mathrm{Ob}, \mathrm{Ob}$ control; Ob-E, Ob-ethanol.

\subsection{Cognitive Effects of Ethanol Consumption}

A novel object recognition test was used to assess short- $(1 \mathrm{~h})$ and long-term $(24 \mathrm{~h})$ memory alterations. No significant differences were observed between the wild-type (C, E) and $\mathrm{Ob}(\mathrm{Ob}, \mathrm{Ob}-\mathrm{E})$ groups (Figure 2).

\subsection{Effects of Ethanol Intake on GR and GPx Activity}

In this experiment, the enzymatic activity of brain GR and GPx was assessed. Figure 3 reflects the effects of ethanol administration on GPx and GR activity (Figure 3a,b, respectively). One-way ANOVA showed significant differences in GR enzymatic activity for the $\mathrm{Ob}-\mathrm{E}$ group. Greater GR activity values were found for the Ob-E group as compared to the rest of the groups $(* p<0.05)$. 


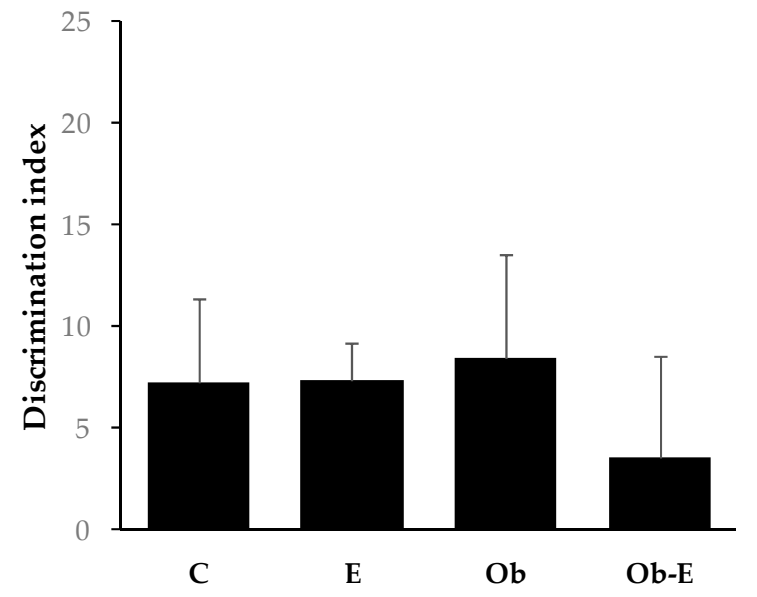

(a)

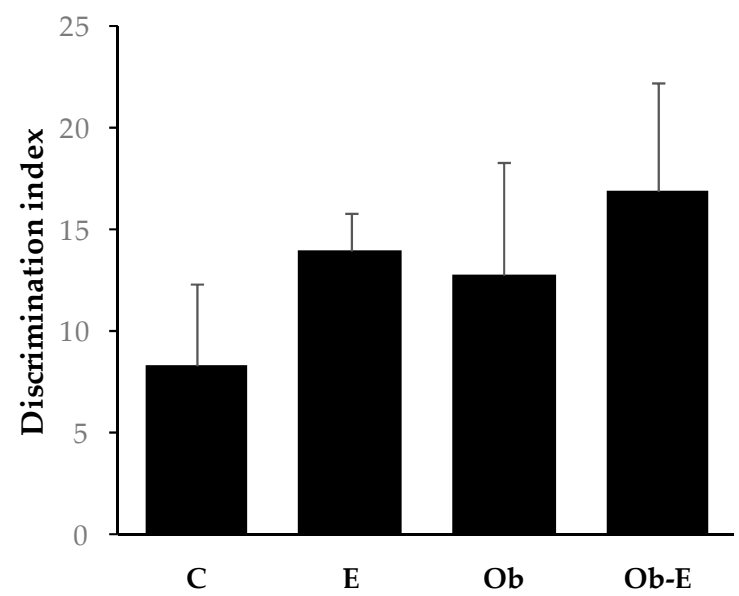

(b)

Figure 2. Effects of chronic ethanol exposure on wild-type and $\mathrm{Ob}$ mice in the object memory recognition task. Bars represent the mean \pm SEM of the discrimination index evaluated at $1 \mathrm{~h}$ (short-term memory) (a) and $24 \mathrm{~h}$ (long-term memory) (b). Discrimation index is defined as DI $=\left[\left(t_{\text {novel }}-t_{\text {familiar }}\right) /\left(t_{\text {novel }}+t_{\text {familiar }}\right) \times 100 \%\right]$. C, wild-type control; E, wild-type ethanol; $\mathrm{Ob}, \mathrm{Ob}$ control; Ob-E, Ob-ethanol.

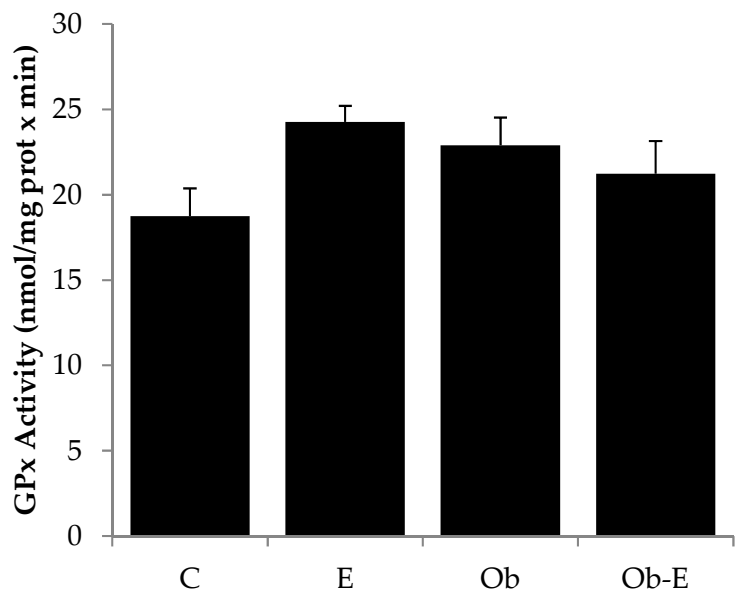

(a)

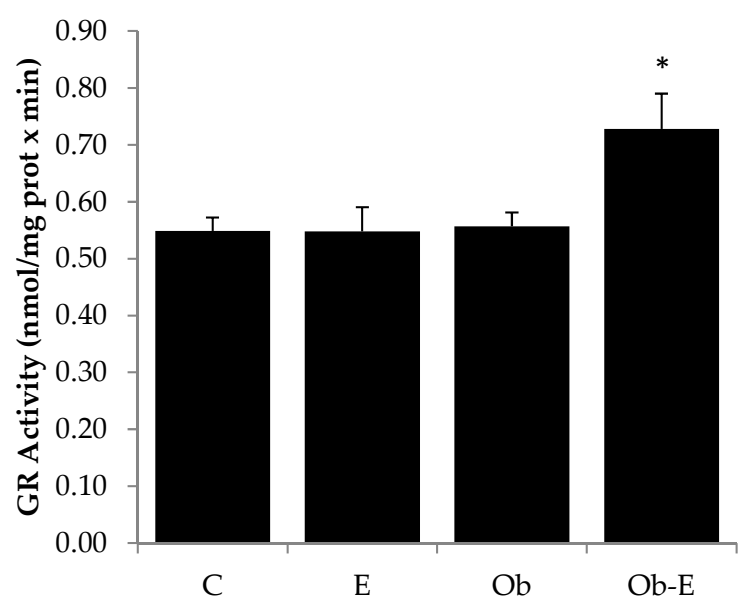

(b)

Figure 3. Effect of chronic ethanol exposure on enzymatic glutathione peroxidase (GPx) (a) and glutathione reductase (GR) activity (b) in the brain. Bars represent the mean \pm SEM.* $p<0.05$ vs. rest of groups. C, wild-type control; E, wild-type ethanol; $\mathrm{Ob}, \mathrm{Ob}$ control; Ob-E, Ob-ethanol.

\subsection{Effects of Ethanol Consumption on GSH, GSSG, GSH/GSSG Ratio, and L-Cysteine}

No significant differences were observed in brain GSH levels after 6 weeks of ethanol consumption (Figure 4a). One-way ANOVA showed significant differences in brain glutathione disulfide (GSSG) concentrations. Post hoc comparisons indicated decreased GSSG concentrations in the $\mathrm{E}, \mathrm{Ob}$, and $\mathrm{Ob}-\mathrm{E}$ groups as compared to the $\mathrm{C}$ group (Figure $4 \mathrm{~b}$; $p<0.05)$. With regard to the brain GSH/GSSG ratio, one-way ANOVA showed significant differences for the $\mathrm{Ob}$ versus $\mathrm{C}$ groups and for the $\mathrm{Ob}-\mathrm{E}$ versus $\mathrm{E}$ and $\mathrm{C}$ groups (Figure 4c; $p<0.05)$. Post hoc comparisons demonstrated an increased GSH/GSSG ratio in Ob mice when compared to the $\mathrm{C}$ group, and in the $\mathrm{Ob}-\mathrm{E}$ group versus the $\mathrm{C}$ and $\mathrm{E}$ groups.

We also measured L-cysteine concentrations in mouse brain samples. Post hoc comparisons indicated increased $\mathrm{Ob}-\mathrm{E}$ brain L-cysteine concentrations as compared to the $\mathrm{C}$ group (Figure $4 \mathrm{~d}, p<0.05$ ). 


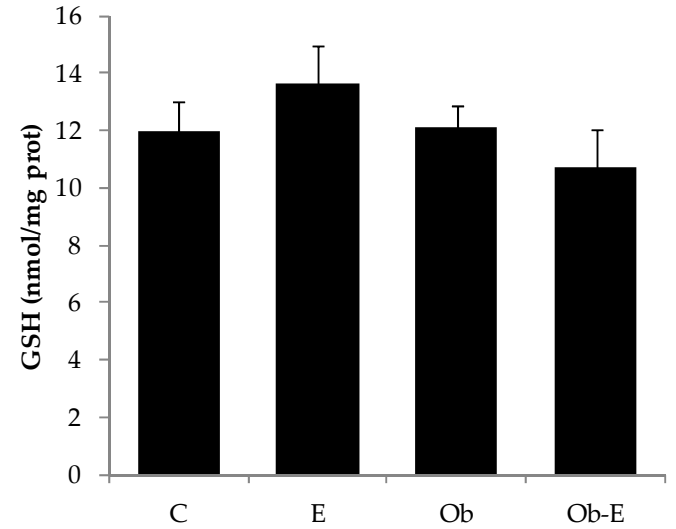

(a)

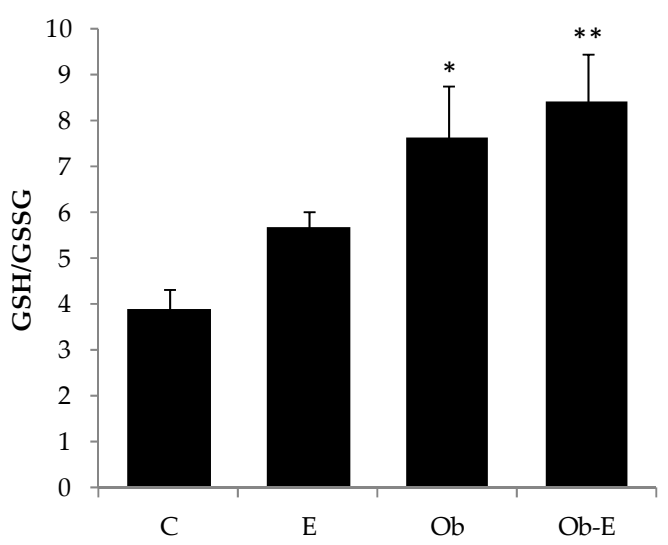

(c)

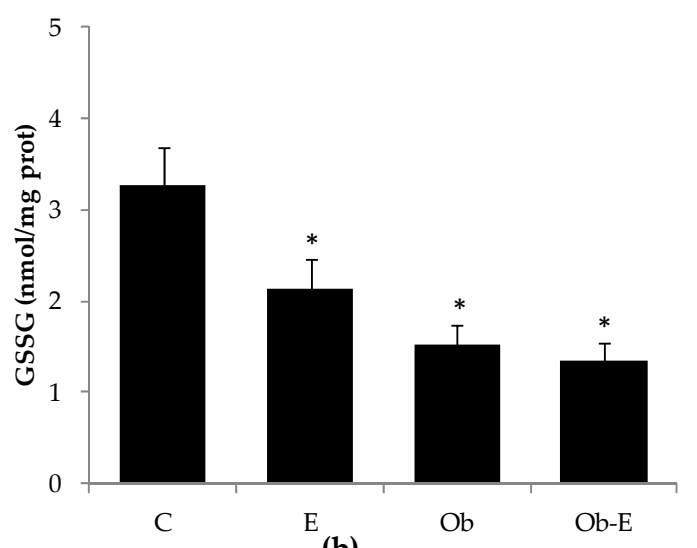

(b)

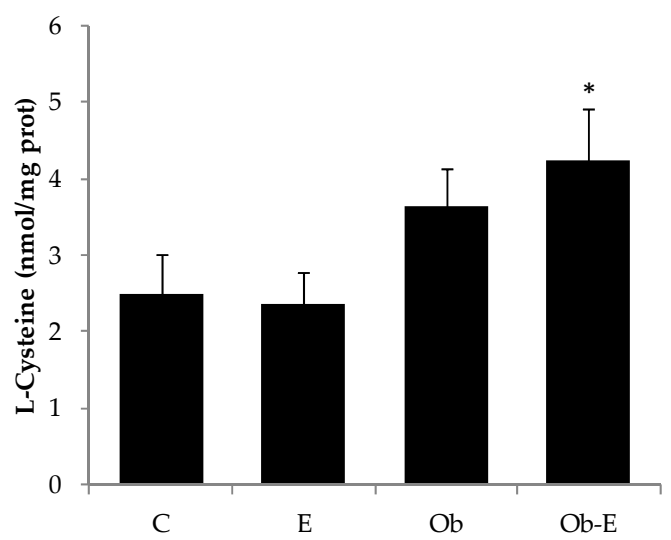

(d)

Figure 4. Effect of chronic ethanol exposure on brain glutathione (GSH) concentrations (a), glutathione disulfide (GSSG) concentrations (b) $\left({ }^{*} p<0.05\right.$ vs. C), GSH/GSSG ratio (c) $\left({ }^{*} p<0.05\right.$ vs. C, ${ }^{* *} p<0.05$ vs. C and E), and L-cysteine values (d) ${ }^{*} p<0.05$ vs. C and E). Bars represent the mean \pm SEM. C, wild-type control; E, wild-type ethanol; Ob, Ob control; Ob-E, Ob-ethanol.

\subsection{Effects of Ethanol Administration on MDA Levels}

Oxidative damage to macromolecules was evaluated using the lipid peroxidation product MDA. One-way ANOVA showed no significant differences among groups (Figure 5).

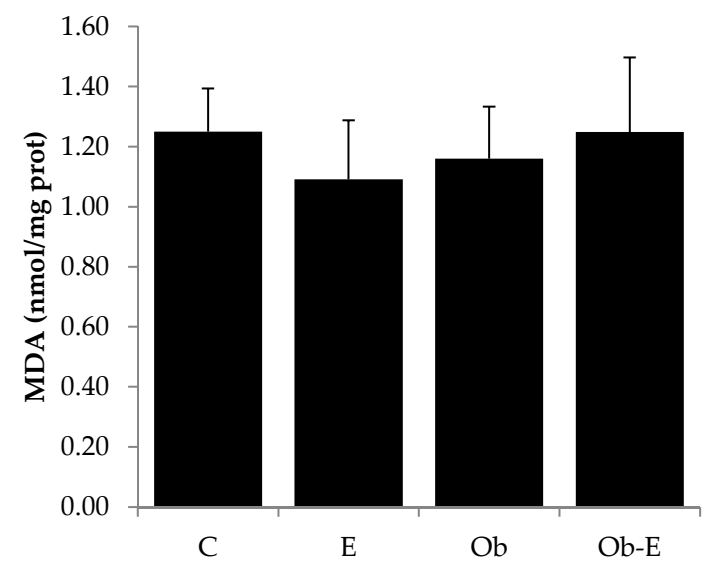

Figure 5. Effects of chronic ethanol administration on MDA concentrations. Bars represent the mean \pm SEM. C, wild-type control; E, wild-type ethanol; Ob, Ob control; Ob-E, Ob-ethanol. 


\section{Discussion}

The results obtained in the present study showed that chronic ethanol intake improved fasting glycemic values but induced impaired glucose tolerance in MS model mice. Importantly, when measured over the time course of the experiment, no differences in weight were observed between the MS Ob mutant and Ob-E mice. Insulin levels in the $\mathrm{Ob}$ groups were significantly increased as compared to the wild-type, $\mathrm{C}$, and $\mathrm{E}$ groups. As reported in the literature, this MS genetic model is defined (among other characteristics) by insulin resistance that leads to an altered glycemic response and hyperglycemia. Moreover, there was an increase in GR activity, GSH/GSSG ratio, and L-cysteine levels, indicating a compensatory mechanism due to the ethanol-elicited oxidative aggression after chronic ethanol intake.

\subsection{MS Mice Model and Chronic Ethanol Consumption}

In the present study, a MS genetic mouse model was used (B6.Cg-LepOb). Use of this model (known as $\mathrm{Ob}$ ) is efficient because of the shortened time required for the development of MS as compared to the diet-induced MS model. In this regard, Ob mice are visually obese practically upon arrival and after 4 weeks of age the growing curve changes drastically and continues to increase even after 12 months of age. These mice have mild hyperglycemia, which transiently changes over time until sustained glucose blood levels of around $400 \mathrm{mg} / \mathrm{dL}$ are achieved. Interestingly, it is common to find peaking glucose elevations which result in $\beta$-cell failure. Moreover, this Ob model has elevated plasma cholesterol levels $[36,37]$. The ethanol intoxication model used in this study has been reported to achieve pharmacologically relevant blood ethanol concentrations [38,39].

Chronic ethanol consumption modulates glycemic levels and acute glycemic response. Insulin levels within the MS groups were increased when compared to those of wild-type animals (Figure 1c). It has been reported that chronic ethanol administration enhances cellular insulin levels [19-22]. One of the molecular mechanisms involved relates to an ethanol-dependent increase in intracellular cAMP levels through a $\mathrm{Ca}^{2+}$-dependent mechanism. The intracellular calcium release elicited by ethanol may play a prominent role as a mechanism involved in cellular insulin release $[29,40]$ and the consequential observed hypoglycemia. Interestingly, as mentioned above, insulin levels within the MS groups (both $\mathrm{Ob}$ and $\mathrm{Ob}-\mathrm{E}$ ) were increased when compared to those of wild-type animals (Figure 1c) indicating that ethanol administration did not modify the impaired cellular insulin homeostasis of $\mathrm{Ob}$ mice. It is well known that $\beta$-cells compensate for the insulin resistance characteristic of this metabolic disorder, with an increase in secretory capacity or in beta-cell mass $[36,37,40]$. Moreover, insulin resistance appears to be a mechanism that overloads $\beta$-cells. This leads to malfunction and apoptosis [41], which result in the characteristic clinical manifestations of T2D: hypoinsulinemia and hyperglucagonemia [42,43]. In this respect, different mechanisms elicited by chronic ethanol administration have been described in the regulation of beta cell function [44]. On one hand, it has been described that chronic ethanol intake modulates glycemic levels through an increase in insulin release [19-22]. On the other hand, several authors have reported that the modulation of glycemic levels by ethanol is linked to its positive correlation with the development of abdominal obesity, which results in an increase in free fatty acid levels and lipogenesis. In this regard, mechanisms such as proinflammatory adipokine activity, glucokinase dysregulation, or GABA receptor inhibition underlie pancreatic beta-cell dysfunction and insulin release dysregulation [45-48]. While in our experimental conditions insulin levels were not modified by ethanol administration, we demonstrated that the acute glycemic response after a glucose overload worsened in the Ob-E group as compared to the $\mathrm{Ob}$ group (Figure 1d). Interestingly, fasting glycemic levels in chronic ethanol-treated MS animals were reduced to normal control values (Figure 1b). Moreover, it was also shown that ethanol administration in wild-type animals also reduced glycemia. It is known that ethanol metabolism inhibits gluconeogenesis and as a result, hepatic glucose production is initially upheld by glycogenolysis. Once the hepatic glycogen stores are depleted hypo- 
glycemia may occur, explaining the late hypoglycemic effect of ethanol [49]. In addition, ethanol-induced hypoglycemia may be associated with blunted nocturnal growth hormone response, impaired counterregulatory response, and impaired ketogenesis [50]. Type 2 diabetes is a progressive disease which typically starts with a gradual loss of glycemic control after meals followed by the development of fasting hyperglycemia [51,52]. Our results indicate that ethanol causes a deterioration in postprandial glucose (Figure 1d) before fasting glucose (Figure $1 \mathrm{~b}$ ) in Ob mice. This supports the idea of a time-dependent effect of ethanol on cellular glycemic homeostasis. Preliminary data obtained in our laboratory demonstrated that ethanol administration to MS animals for 6 months aggravated the glucose overload response and reduced insulin release in Ob-E mice. Further studies are necessary to demonstrate whether this reduction is due to the overload, malfunction, or apoptosis of $\beta$-cells characteristic of T2D.

\subsection{Chronic Ethanol Consumption and MS Modulate Oxidative Status in the Brain of Mice}

Postprandial hyperglycemia may induce oxidative stress [53], and central ethanol metabolism plays a critical role in the disruption and loss of the cellular oxidative balance [54]. There is a large body of evidence indicating that at a central level, ethanol is oxidized through a catalase- $\mathrm{H}_{2} \mathrm{O}_{2}$ system. This oxidative reaction results in the production of ethanol's first oxidative metabolite, acetaldehyde, which is highly reactive and responsible for cell injury [55-58]. In our experimental conditions, we observed that ethanol administration was able to increase brain GR activity as well as the GSH/GSSG ratio and L-cysteine concentrations in Ob-E mice (Figure 4). These results support the hypothesis of a compensatory mechanism after an oxidative insult based on a temporary cellular increase in antioxidant defense to restore the original homeostatic conditions $[59,60]$. Due to the formation of reactive species the glutathione system is activated to reestablish cell redox balance. When a harmful oxidant agent is present in the cell, GPx is activated, reducing the reactive species and oxidizing GSH to its disulfide form (GSSG). Thus, GSSG is reduced to GSH through GR enzyme activity, restoring initial GSH concentrations. In this process, GSH and its disulfide form GSSG remain in constant enzyme substrate turnover. Our data showed an increase in GR activity which was not accompanied an enhanced GPx activity, thus justifying the reduced GSSG concentration and increased GSH/GSSG ratio. Other studies have found an increase in the enzymatic activity of GPx after ethanol administration $[61,62]$. This discrepancy may be due to the fact that these studies explored the acute effects of ethanol administration. There is a large body of evidence indicating that in the brain, acetaldehyde is directly formed via the catalase- $\mathrm{H}_{2} \mathrm{O}_{2}$ system [54]. In this respect it may be hypothesized that after 6 weeks of ethanol administration GPx activity does not increase because its substrate, $\mathrm{H}_{2} \mathrm{O}_{2}$, appears to be reduced by the catalase system. Moreover, we observed an increase in brain L-cysteine concentrations in the Ob-E group (Figure 4). The increase in levels of this antioxidant supports the hypothesis of a compensatory mechanism [63]. Thus, in animals with MS, chronic ethanol administration modulates GSH metabolism, resulting in elevated concentrations of at least one of its forming peptides.

With respect to brain MDA concentrations, lipid peroxidation is a process which involves the oxidation of polyunsaturated fatty acids present in the biological membranes. The products of this lipid peroxidation (such as MDA) yield several DNA adducts, are extremely mutagenic, and cause protein damage [64-66]. It has been demonstrated that lipid peroxidation can be increased by ethanol administration, which is accompanied by diminished cell antioxidant defense $[67,68]$. However, in our experimental conditions this ethanol-induced peroxidative damage appeared to be offset by the increased response of the cellular antioxidant system (Figures 3 and 4).

\subsection{Behavioral Effects of Chronic Ethanol Consumption in MS Mice}

At the behavioral level, 6 weeks of chronic ethanol administration modulated different processes involved in glucose homeostasis, acute glycemic response, and brain oxidative 
status, but did not have behavioral effects in our model of MS. In this respect, different authors have found behavioral alterations within the same time-course of ethanol administration. However, the experimental procedure used to obtain the effects of ethanol intoxication was based on a different diet (Lieber-de-Carli) [67]. Thus, in our experimental conditions, short- and long-term recognition memory processes were not affected. In fact, this ethanol administration model was proven to produce behavioral impairment after 5 months of ethanol consumption [38,39].

\section{Materials and Methods}

\subsection{Animals}

A total of 96 male C57BL6 and B6.Cg-Lep ${ }^{\mathrm{Ob}}$ (Janvier Labs, Le Genest-Saint-Isle, France) mice were used in this study. The animals, which were 4 weeks of age upon arrival, were housed five per cage in an acclimated quarantine room in which they remained for a week. After this period, mice were moved into the colony room for a week before ethanol exposure. Mice were 6 weeks of age when ethanol was introduced for 6 weeks. The colony room was maintained at a temperature of $21 \pm 1^{\circ} \mathrm{C}$, and controlled under a 12-h light/dark cycle (lights on at 8:00 a.m.). Food and water were provided ad libitum throughout the study. All experimental procedures complied with the European Community Council Directive (2010/63/EU) and were approved by the Animal Health department of Generalitat Valenciana (project code: 2019/VSC/PEA/0053, approved date: 11 March 2019).

\subsection{Drugs and Chemicals}

Ethanol (Panreac, Barcelona, Spain) was diluted to $12 \%(v / v)$ in water and administered.

To prepare working solutions and assay reactants potassium hydrogenphophate, potassium dihydrogenphosphate, glutathione oxidized, glutathione reduced, L-cysteine, 1-fluoro-2,4-dinitrobencene, iodoacetic acid, perclhoric acid, glacial acetic acid, sodium acetate, ethylenediaminetetraacetic acid (EDTA), sodium azide $\left(\mathrm{NaN}_{3}\right), \mathrm{GSH}$ disulfide reductase (GR), hydrogen peroxide 30\%, 5,5'-dithiobis(2-nitrobenzoic acid) (DTNB), sodium hydrogenphophate, sodium dihydrogenphosphate, 2-thiobarbituric acid and 1,1,3,3-tetramethoxypropane were purchased from Sigma-Aldrich (Darmstadt, Germany). Methanol and NADPH were purchased from Scharlab (Barcelona, Spain) and Panreac (Barcelona, Spain), respectively. High-purity water was obtained from a Millipore System (Merk Millipore, Burlington, MA, USA).

\subsection{Experimental Procedure}

Animals were divided into four groups ( $n=10-12$ per group): wild-type control (C), wild-type ethanol (E), MS control (Ob), and MS ethanol (Ob-E). The E and Ob-E groups were exposed to ethanol $(12 \% v / v)$ in drinking water for 6 weeks. To avoid treatment rejection, the ethanol concentration was scaled over a 2 -week habituation period $(0 \%, 2 \%$, $4 \%, 6 \%, 8 \%, 10 \%$, and $12 \%$, every $48 \mathrm{~h}$ ). The blood ethanol levels achieved in the $\mathrm{E}$ and $\mathrm{Ob}-\mathrm{E}$ groups were $108.5 \pm 18.0 \mathrm{mg} / \mathrm{dL}$ and $95.6 \pm 22.6 \mathrm{mg} / \mathrm{dL}$, respectively.

Weight, glycemia, and liquid consumption values were determined once a week, $2 \mathrm{~h}$ after lights were turned on. Animals were moved from their home cages to the procedure room $30 \mathrm{~min}$ before the start of each experiment, allowing them to acclimatize to the environmental conditions. Finally, animals were sacrificed using cervical dislocation. Blood samples and brain samples were frozen to $-80{ }^{\circ} \mathrm{C}$ for further analysis. Prior to freezing, brain samples were homogenized in prechilled $0.2 \mathrm{M}$ potassium phosphate buffer, $\mathrm{pH} 7$.

\subsubsection{Glycemia, Insulinemia, and Glucose Overload Tests}

Glycemia was measured weekly through the collection of $1 \mu \mathrm{L}$ of blood from the mouse tail. Glucose levels were then measured using an ACCU-CHECK glucometer (Roche Diagnostics, Rotkreuz, Switzerland). Blood insulin levels were assayed using an Elisa Kit (Merk, Darmstad, Germany). For the glucose overload test, fasting mice (12 h) 
were treated with glucose ( $2 \mathrm{~g} / \mathrm{kg}$ i.p.), and blood glucose levels were determined after 30,60 , and $120 \mathrm{~min}$. Glycemic values at 30, 60, and $120 \mathrm{~min}$ were represented as a \% of increase versus time 0 .

\subsubsection{Memory and Learning Test}

Short- and long-term memory, as well as the behavioral effects of ethanol, were evaluated using the object recognition test. Briefly, a 40-cm diameter cylinder with sawdust on the floor was set down in a testing room with faint light. Two red plastic blocks were placed inside the cylinder and a mouse was allowed to inspect objects for 5 min (training session). To measure short-term memory, one of the blocks was changed to a round yellow block. All the objects were heavy enough to prevent displacement. One hour after the end of the training session animals were placed in the middle of the cylinder and allowed to explore the objects for $5 \mathrm{~min}$ to evaluate short-term memory. The experiment was repeated $24 \mathrm{~h}$ after the end of the training session to evaluate longterm memory. The orientation of the animal's snout toward the object within a range of $2 \mathrm{~cm}$ or less from the object was defined as object exploration. Sitting on the object or running around it was not recorded as exploration. Objects were washed with ethanol after each individual trail to equate olfactory cues. The discrimination index, calculated as [DI $\left.=\left(t_{\text {novel }}-t_{\text {familiar }}\right) /\left(t_{\text {novel }}+t_{\text {familiar }}\right) \times 100 \%\right]$, was used as a basic measure in the object recognition test [38].

The oxidative status of brain samples was evaluated as follows:

\subsubsection{Antioxidant Defenses}

Glutathione (L-Glutamyl-L-cysteinyl-glycine) is a tripeptide with multiple cellular functions. Glutathione is the main antioxidant system in the cell and a detoxification agent for ROS and reactive nitrogen species. There are two forms of glutathione: the oxidized form (GSSG) and the reduced form (GSH). The GSH/GSSG redox couple is a cosubstrate for glutathione peroxidase and reductase enzymes (GPx and GR) which act as a vital cellular redox buffer modulating different sensitive biochemical and biophysical processes. L-cysteine is a glutathione biosynthesis precursor used as an oxidative stress biomarker [69].

GSH, GSSG, and L-Cysteine

GSH, GSSG, and L-cysteine concentrations were chromatographically quantified using Reed's method [70]. This method derivatizes the amino groups with 1-fluoro-2,4dinitrobencene (Sanger reactant) after blocking the free thiol groups with iodoacetic acid. Briefly, samples $(180 \mu \mathrm{L}$ with $20 \mu \mathrm{L}$ perclhoric acid $20 \%)$ were centrifuged, and then iodoacetid acid $(40 \mu \mathrm{L}, 0.1 \mathrm{M})$ was added. After adjusting to $\mathrm{pH} 9$ and with obscurity and ice-cold incubation for $30 \mathrm{~min}$, Sanger reactant $(200 \mu \mathrm{L})$ was added. Samples were then incubated overnight at $4{ }^{\circ} \mathrm{C}$. Samples were centrifuged and filtered through a $22-\mu \mathrm{m}$ nylon filter prior to the chromatographic analysis. The high-performance liquid chromatography (HPLC) working solutions were methanol:water (4:1, v/v) (mobile phase A) and methanol:sodium acetate buffer $3.45 \mathrm{M} \mathrm{pH} 5.3(64: 36, v / v)$ (mobile phase B). Separation was carried out using a Kromasyl-NH2 $250 \times 4.6 \mathrm{~mm} 5 \mu \mathrm{m}$ column (Waters Corporation, Mildford, MA, USA), and the UV-Vis detector was set at $365 \mathrm{~nm}$. The separation gradient was $20 \%$ B from initial time to $10 \mathrm{~min}$, which was then increased linearly to $80 \% \mathrm{~B}$ at $45 \mathrm{~min}$ at a $1 \mathrm{~mL} / \mathrm{min}$ flow.

Glutathione Peroxidase Activity (GPx)

GPx was measured by monitoring the disappearance of NADPH at $340 \mathrm{~nm}$ [71]. Briefly, $50-\mu \mathrm{L}$ samples were mixed with potassium phosphate buffer $0.1 \mathrm{M} \mathrm{pH} 7.0(550 \mu \mathrm{L})$ containing ethylenediaminetetraacetic acid (EDTA), $\mathrm{NaN}_{3}$ (both $1 \mathrm{mM}$ ), and $100 \mu \mathrm{L}$ of the following solutions: GSH disulfide reductase $(0.24 \mathrm{U} / \mathrm{mL})$, reduced glutathione $(1 \mathrm{mM})$, and NADPH $(0.15 \mathrm{mM})$. After incubation $\left(3 \mathrm{~min}\right.$ at $\left.37^{\circ} \mathrm{C}\right)$, a reaction was started by the addition of hydrogen peroxide $1.5 \mathrm{mM}(100 \mu \mathrm{L})$. 
Glutathione Reductase Activity (GR)

GR was determined spectrophotometrically using Smith's proposed method [72]. Briefly, when the GR catalyzed reduction of GSSG to GSH was produced in presence of 5,5'-dithiobis(2-nitrobenzoic acid) (DTNB), 2-nitrobenzoic acid was formed as a subproduct. Formation was monitored at $412 \mathrm{~nm}$. The GSSG reduction was started by adding $25 \mu \mathrm{L}$ of brain sample to a solution containing DTNB $3 \mathrm{mM}$ prepared in $10 \mathrm{mM}$ sodium phosphate buffer, $2 \mathrm{mM} \mathrm{NADPH}$, and $10 \mathrm{mM}$ EDTA in $0.2 \mathrm{M} \mathrm{pH} 7.5$ sodium phosphate buffer.

The oxidative damage to macromolecules was evaluated as follows:

Lipid peroxidation or reaction of oxygen with unsaturated lipids produces a wide variety of oxidation products. One of the main primary products and a biomarker for lipid peroxidation is MDA, which appears to be the most mutagenic and cell-toxic agent [73].

\subsubsection{Lipid Peroxidation}

MDA concentrations were determined chromatographically using an HPLC system equipped with a fluorescence detector (set to $527 \mathrm{~nm}$ for excitation and $532 \mathrm{~nm}$ for emission). Sample preparation consisted of mixing samples $(100 \mu \mathrm{L})$ with $0.75 \mathrm{~mL}$ of thiobarbituric acid $0.37 \%$ and perchloric acid $6.4 \%(2: 1, v / v)$, heating to $95^{\circ} \mathrm{C}$ for an hour. Prior to injection in the HPLC system, the $\mathrm{pH}$ was adjusted to 6 and precipitates were removed by centrifugation (10,000 rpm, $1 \mathrm{~min})$. Separation was carried out in a C18 $250 \times 4.6 \mathrm{~mm} 5 \mu \mathrm{m}$ column (Scharlab, Barcelona, Spain) and flow was set at $1 \mathrm{~mL} / \mathrm{min}$ in an isocratic separation. Mobile phase consisted of a 50-mM potassium phosphate buffer ( $\mathrm{pH}$ 6.0):methanol (58:42, $v / v$ ). Standard solutions were prepared daily from 1,1,3,3-tetramethoxypropane. This method was first proposed by Richard [74] and later modified by Romero and cols. [75].

\subsubsection{Protein Content}

Protein levels were determined from brain lysates in accordance with the method described by Bradford [76] (ThermoFisher Scientific, Waltham, MA, USA).

\subsubsection{Statistical Analysis}

Statistical analyses were carried out using SPSS software (IBM SPSS Statistics for Windows, Version 25.0 IBM Corp, Armonk, NY, USA). Results were presented as mean values $\pm \mathrm{SE}$. Comparisons between groups were made by one-way ANOVA. The analysis of variance of the obtained data was performed by the Levene test, using the LSD test as a post hoc test when the data showed homogeneity in their variances $(p<0.05)$, or a Dunnet T3 test when variances differed. Statistical significance differences were set at the $p<0.05$ level.

\section{Conclusions}

This body of evidence supports the hypothesis that ethanol is a modulating agent of glycemic response in MS mice. This modulation was accompanied by a dysregulation of the brain oxidative status but did not affect short- and long-term memory, indicating moderate effects of ethanol consumption on behavior. However, further studies are required to elucidate the particular mechanisms by which ethanol might modulate the transition from MS to T2D.

Author Contributions: Conceptualization and methodology, M.M., P.B., and R.R.-C.; investigation and experimental procedures, P.B. and R.R.-C.; data analysis, M.M. and P.B.; writing-original draft preparation, R.R.-C. and P.B.; writing-review and editing, M.M. All authors have read and agreed to the published version of the manuscript.

Funding: This research was funded by Universitat Jaume I (UJI), Spain; grant number UJI-A2016-03 and UJI-B2019-38.

Institutional Review Board Statement: The study was conducted according to the guidelines of the Declaration of Helsinki, and approved by the Institutional Animal Ethics Committee of Universitat Jaume I protocol code 2019/VSC/PEA/0053 on 3 June 2019. 


\section{Informed Consent Statement: Not apllicable.}

Data Availability Statement: Data sharing not applicable.

Conflicts of Interest: The authors declare no conflict of interest. The funders had no role in the design of the study; in the collection, analyses, or interpretation of data; in the writing of the manuscript, or in the decision to publish the results.

$\begin{array}{ll}\text { Abbreviations } \\ \text { cAMP } & \text { Cyclic adenosine monophosphate } \\ \text { DI } & \text { Discrimination index } \\ \text { DTNB } & 5,5^{\prime} \text {-dithiobis(2-nitrobenzoic acid) } \\ \text { EDTA } & \text { Ethylenediaminetetraacetic acid } \\ \text { GABA } & \text { Г-aminobutyric acid } \\ \text { GPx } & \text { Glutathione peroxidase activity } \\ \text { GR } & \text { Glutathione reductase activity } \\ \text { GSH } & \text { Glutathione } \\ \text { GSSG } & \text { Glutathione disulfide } \\ \text { HPLC } & \text { High-performance liquid chromatography } \\ \text { L-Cys } & \text { L-cysteine } \\ \text { MDA } & \text { Malondialdehyde } \\ \text { MS } & \text { Metabolic syndrome } \\ \text { NADPH } & \text { Nicotinamide adenine dinucleotide phosphate } \\ \text { T2D } & \text { Type } 2 \text { diabetes } \\ \text { WHO } & \text { World Health Organization }\end{array}$

\section{References}

1. World Health Organization. Global Status Report on Alcohol and Health 2018; World Health Organization: Geneva, Switzerland, 2018.

2. Lorenzo, C.; Okoloise, M.; Williams, K.; Stern, M.P.; Haffner, S.M.; San Antonio Heart Study. The Metabolic Syndrome as Predictor of Type 2 Diabetes: The San Antonio Heart Study. Diabetes Care 2003, 26, 3153-3159. [CrossRef] [PubMed]

3. International Diabetes Federation. The IDF Consensus Worldwide Definition of the Metabolic Syndrome; International Diabetes Federation: Brussels, Belgium, 2006.

4. O'Neill, S.; O'Driscoll, L. Metabolic syndrome: A closer look at the growing epidemic and its associated pathologies. Obes. Rev. 2015, 16, 1-12. [CrossRef] [PubMed]

5. Marott, S.C.W.; Nordestgaard, B.G.; Tybjærg-Hansen, A.; Benn, M. Components of the Metabolic Syndrome and Risk of Type 2 Diabetes. J. Clin. Endocrinol. Metab. 2016, 101, 3212-3221. [CrossRef] [PubMed]

6. Ginsberg, H.N.; Maccallum, P.R. The Obesity, Metabolic Syndrome, and Type 2 Diabetes Mellitus Pandemic: Part I. Increased Cardiovascular Disease Risk and the Importance of Atherogenic Dyslipidemia in Persons With the Metabolic Syndrome and Type 2 Diabetes Mellitus. J. CardioMetab. Syndr. 2009, 4, 113-119. [CrossRef] [PubMed]

7. Li, C.; Hsieh, M.-C.; Chang, S.-J. Metabolic syndrome, diabetes, and hyperuricemia. Curr. Opin. Rheumatol. 2013, 25, 210-216. [CrossRef] [PubMed]

8. Shinkov, A.; Borissova, A.-M.; Kovatcheva, R.; Vlahov, J.; Dakovska, L.; Atanassova, I.; Petkova, P. Increased prevalence of depression and anxiety among subjects with metabolic syndrome and known type 2 diabetes mellitus-A population-based study. Postgrad. Med. 2018, 130, 251-257. [CrossRef] [PubMed]

9. Malik, V.S.; Popkin, B.M.; Bray, G.A.; Després, J.-P.; Willett, W.C.; Hu, F.B. Sugar-Sweetened Beverages and Risk of Metabolic Syndrome and Type 2 Diabetes: A meta-analysis. Diabetes Care 2010, 33, 2477-2483. [CrossRef]

10. Earnest, C.P.; Johannsen, N.M.; Swift, D.L.; Gillison, F.B.; Mikus, C.R.; Lucía, A.; Kramer, K.; Lavie, C.J.; Church, T.S. Aerobic and Strength Training in Concomitant Metabolic Syndrome and Type 2 Diabetes. Med. Sci. Sports Exerc. 2014, 46, 1293-1301. [CrossRef]

11. Wannamethee, S.G.; Shaper, A.G.; Perry, I.J.; Alberti, K.G.M.M. Alcohol consumption and the incidence of type II diabetes. J. Epidemiol. Community Health 2002, 56, 542-548. [CrossRef]

12. Shin, J.-A.; Lee, J.-H.; Lim, S.-Y.; Ha, H.-S.; Kwon, H.-S.; Park, Y.-M.; Lee, W.-C.; Kang, M.-I.; Yim, H.-W.; Yoon, K.-H.; et al. Metabolic syndrome as a predictor of type 2 diabetes, and its clinical interpretations and usefulness. J. Diabetes Investig. 2013, 4, 334-343. [CrossRef]

13. Salim, S. Oxidative Stress and the Central Nervous System. J. Pharmacol. Exp. Ther. 2017, 360, 201-205. [CrossRef] [PubMed]

14. Cobley, J.N.; Fiorello, M.L.; Bailey, D.M. 13 reasons why the brain is susceptible to oxidative stress. Redox Biol. 2018, 15, 490-503. [CrossRef] 
15. Hayden, M.R.; Tyagi, S.C. Islet Redox Stress: The Manifold Toxicities of Insulin Resistance, Metabolic Syndrome and Amylin Derived Islet Amyloid in Type 2 Diabetes Mellitus. JOP 2002, 3, 86-108. Available online: http://www.ncbi.nlm.nih.gov/ pubmed/12110767 (accessed on 8 April 2019). [PubMed]

16. Robertson, R.; Harmon, J.; Tran, P.O.T.; Poitout, V. Cell Glucose Toxicity, Lipotoxicity, and Chronic Oxidative Stress in Type 2 Diabetes. Diabetes 2004, 53 (Suppl. 1), S119-S124. Available online: http:/ /www.ncbi.nlm.nih.gov/pubmed/14749276 (accessed on 8 April 2019). [CrossRef] [PubMed]

17. Bi, Y.; Wang, T.; Xu, M.; Xu, Y.; Li, M.; Lu, J.; Zhu, X.; Ning, G. Advanced research on risk factors of type 2 diabetes. Diabetes Metab. Res. Rev. 2012, 28, 32-39. [CrossRef] [PubMed]

18. Fromenty, B.; Vadrot, N.; Massart, J.; Turlin, B.; Barri-Ova, N.; Letteron, P.; Fautrel, A.; Robin, M.-A. Chronic Ethanol Consumption Lessens the Gain of Body Weight, Liver Triglycerides, and Diabetes in Obese ob/ob Mice. J. Pharmacol. Exp. Ther. 2009, 331, 23-34. [CrossRef] [PubMed]

19. Schaller, G.; Kretschmer, S.; Gouya, G.; Haider, D.G.; Mittermayer, F.; Riedl, M.; Wagner, O.; Pacini, G.; Wolzt, M.; Ludvik, B. Alcohol Acutely Increases Vascular Reactivity together with Insulin Sensitivity in Type 2 Diabetic Men. Exp. Clin. Endocrinol. Diabetes 2009, 118, 57-60. [CrossRef]

20. Koppes, L.L.J.; Dekker, J.M.; Hendriks, H.F.; Bouter, L.M.; Heine, R.J. Moderate Alcohol Consumption Lowers the Risk of Type 2 Diabetes: A Meta-Analysis of Prospective Observational Studies. Diabetes Care 2005, 28, 719-725. Available online: http:/ / www.ncbi.nlm.nih.gov/pubmed/15735217 (accessed on 8 April 2019). [CrossRef]

21. Howard, A.A.; Arnsten, J.H.; Gourevitch, M.N. Effect of Alcohol Consumption on Diabetes Mellitus: A Systematic Review. Ann. Intern. Med. 2004, 140, 211-219. Available online: http://www.ncbi.nlm.nih.gov/pubmed/14757619 (accessed on 7 April 2019). [CrossRef]

22. Knott, C.S.; Bell, S.; Britton, A. Alcohol Consumption and the Risk of Type 2 Diabetes: A Systematic Review and Dose-Response Meta-analysis of More Than 1.9 Million Individuals from 38 Observational Studies. Diabetes Care 2015, 38, 1804-1812. [CrossRef]

23. Liu, L.; Wang, Y.; Lam, K.S.L.; Xu, A. Moderate Wine Consumption in the Prevention of Metabolic Syndrome and Its Related Medical Complications. Endocr. Metab. Immune Disord. Drug Targets 2008, 8, 89-98. Available online: http://www.ncbi.nlm.nih. gov/pubmed/18537695 (accessed on 8 April 2019). [CrossRef]

24. Li, X.-H.; Yu, F.-F.; Zhou, Y.-H.; He, J. Association between alcohol consumption and the risk of incident type 2 diabetes: A systematic review and dose-response meta-analysis. Am. J. Clin. Nutr. 2016, 103, 818-829. [CrossRef]

25. Pietraszek, A.; Gregersen, S.; Hermansen, K. Alcohol and type 2 diabetes. A review. Nutr. Metab. Cardiovasc. Dis. 2010, 20, 366-375. [CrossRef]

26. Baliunas, D.; Taylor, B.J.; Irving, H.; Roerecke, M.; Patra, J.; Mohapatra, S.; Rehm, J. Alcohol as a Risk Factor for Type 2 Diabetes: A systematic review and meta-analysis. Diabetes Care 2009, 32, 2123-2132. [CrossRef]

27. Huang, J.; Wang, X.; Zhang, Y. Specific types of alcoholic beverage consumption and risk of type 2 diabetes: A systematic review and meta-analysis. J. Diabetes Investig. 2017, 8, 56-68. [CrossRef]

28. De Gaetano, G.; Costanzo, S.; Di Castelnuovo, A.; Badimon, L.; Bejko, D.; Alkerwi, A.; Chiva-Blanch, G.; Estruch, R.; La Vecchia, C.; Panico, S.; et al. Effects of moderate beer consumption on health and disease: A consensus document. Nutr. Metab. Cardiovasc. Dis. 2016, 26, 443-467. [CrossRef]

29. Cofán, M.; Nicolas, J.M.; Sola-Fernandez, J.; Robert, J.; Tobias, E.; Sacanella, E.; Estruch, R.; Urbano-Marquez, A. Acute Ethanol Treatment Decreases Intracellular Calcium-Ion Transients in Mouse Single Skeletal Muscle Fibres In Vitro. Alcohol Alcohol. 2000, 35, 134-138. Available online: http:/ /www.ncbi.nlm.nih.gov/pubmed/10787387 (accessed on 8 April 2019). [CrossRef]

30. De Beun, R.; Schneider, R.; Klein, A.; Lohmann, A.; Schreiber, R.; De Vry, J. The calcium channel agonist BAY k 8644 reduces ethanol intake and preference in alcohol-preferring AA rats. Psychopharmacology 1996, 127, 302-310. [CrossRef]

31. Masalkar, P.D.; Abhang, S.A. Oxidative stress and antioxidant status in patients with alcoholic liver disease. Clin. Chim. Acta 2005, 355, 61-65. [CrossRef]

32. Rehman, K.; Akash, M.S.H. Mechanism of Generation of Oxidative Stress and Pathophysiology of Type 2 Diabetes Mellitus: How Are They Interlinked? J. Cell. Biochem. 2017, 118, 3577-3585. [CrossRef]

33. Sakuraba, H.; Mizukami, H.; Yagihashi, N.; Wada, R.; Hanyu, C.; Yagihashi, S. Reduced beta-cell mass and expression of oxidative stress-related DNA damage in the islet of Japanese Type II diabetic patients. Diabetologia 2002, 45, 85-96. [CrossRef]

34. Ford, E.S.; Mokdad, A.H.; Giles, W.H.; Brown, D.W. The Metabolic Syndrome and Antioxidant Concentrations: Findings From the Third National Health and Nutrition Examination Survey. Diabetes 2003, 52, 2346-2352. [CrossRef]

35. Demircan, N.; Gurel, A.; Armutcu, F.; Ünalacak, M.; Aktunc, E.; Atmaca, H.M. The evaluation of serum cystatin C, malondialdehyde, and total antioxidant status in patients with metabolic syndrome. Med. Sci. Monit. 2008, 14, CR97-CR101.

36. Kennedy, A.J.; Ellacott, K.L.; King, V.L.; Hasty, A.H. Mouse models of the metabolic syndrome. Dis. Model. Mech. 2010, 3, 156-166. [CrossRef]

37. Wong, S.K.; Chin, K.-Y.; Suhaimi, F.H.; Fairus, A.; Soelaiman, I.N. Animal models of metabolic syndrome: A review. Nutr. Metab. 2016, 13, 65. [CrossRef]

38. Pascual, M.; Baliño, P.; Alfonso-Loeches, S.; Aragón, C.M.G.; Guerri, C. Impact of TLR4 on behavioral and cognitive dysfunctions associated with alcohol-induced neuroinflammatory damage. Brain Behav. Immun. 2011, 25 (Suppl. 1), S80-S91. [CrossRef]

39. Pascual, M.; Baliño, P.; Aragón, C.M.G.; Guerri, C. Cytokines and chemokines as biomarkers of ethanol-induced neuroinflammation and anxiety-related behavior: Role of TLR4 and TLR2. Neuropharmacology 2015, 89, 352-359. [CrossRef] 
40. Baliño, P.; Ledesma, J.C.; Aragón, C.M.G. In Vivo Study of Ethanol-Activated Brain Protein Kinase A: Manipulations of Ca ${ }^{2+}$ Distribution and Flux. Alcohol. Clin. Exp. Res. 2014, 38, 629-640. [CrossRef]

41. Kahn, S.E. The relative contributions of insulin resistance and beta-cell dysfunction to the pathophysiology of Type 2 diabetes. Diabetologia 2003, 46, 3-19. [CrossRef]

42. Yagihashi, S. Advances in pathology of diabetes from pancreatic islets to neuropathy-a tribute to Paul Langerhans. Pathol. Int. 2015, 65, 157-169. [CrossRef]

43. Yagihashi, S.; Inaba, W.; Mizukami, H. Dynamic pathology of islet endocrine cells in type 2 diabetes: $\beta$-Cell growth, death, regeneration and their clinical implications. J. Diabetes Investig. 2016, 7, 155-165. [CrossRef]

44. Steiner, J.L.; Crowell, K.T.; Lang, C.H. Impact of Alcohol on Glycemic Control and Insulin Action. Biomolecules 2015, 5, 2223-2246. [CrossRef]

45. Esser, N.; Legrand-Poels, S.; Piette, J.; Scheen, A.J.; Paquot, N. Inflammation as a link between obesity, metabolic syndrome and type 2 diabetes. Diabetes Res. Clin. Pr. 2014, 105, 141-150. [CrossRef]

46. Patel, D.; Singh, S.P. Effect of ethanol and its metabolites on glucose mediated insulin release from isolated islets of rats. Metabolism 1979, 28, 85-89. [CrossRef]

47. Kim, J.Y.; Hwang, J.-Y.; Lee, D.Y.; Song, E.H.; Park, K.J.; Kim, G.H.; Jeong, E.A.; Lee, Y.J.; Go, M.J.; Kim, D.J.; et al. Chronic Ethanol Consumption Inhibits Glucokinase Transcriptional Activity byAtf3and Triggers Metabolic Syndromein Vivo. J. Biol. Chem. 2014, 289, 27065-27079. [CrossRef] [PubMed]

48. Wang, S.; Luo, Y.; Feng, A.; Li, T.; Yang, X.; Nofech-Mozes, R.; Yu, M.; Wang, C.; Li, Z.; Yi, F.; et al. Ethanol induced impairment of glucose metabolism involves alterations of GABAergic signaling in pancreatic $\beta$-cells. Toxicology 2014, 326, 44-52. [CrossRef] [PubMed]

49. Van De Wiel, A. Diabetes mellitus and alcohol. Diabetes Metab. Res. Rev. 2004, 20, 263-267. [CrossRef] [PubMed]

50. Tetzschner, R.; Nørgaard, K.; Ranjan, A.G. Effects of alcohol on plasma glucose and prevention of alcohol-induced hypoglycemia in type 1 diabetes-A systematic review with GRADE. Diabetes Metab. Res. Rev. 2018, 34, e2965. [CrossRef]

51. Monnier, L.; Colette, C.; Dunseath, G.J.; Owens, D.R. The Loss of Postprandial Glycemic Control Precedes Stepwise Deterioration of Fasting With Worsening Diabetes. Diabetes Care 2007, 30, 263-269. [CrossRef]

52. Pratley, R.E.; Weyer, C. The role of impaired early insulin secretion in the pathogenesis of Type II diabetes mellitus. Diabetologia 2001, 44, 929-945. [CrossRef]

53. Ceriello, A. The possible role of postprandial hyperglycaemia in the pathogenesis of diabetic complications. Diabetologia 2003, 46, M9-M16. [CrossRef] [PubMed]

54. Baliño, P.; Romero-Cano, R.; Sánchez-Andrés, J.V.; Valls, V.; Aragón, C.G.; Muriach, M.; Romero, R. Effects of Acute Ethanol Administration on Brain Oxidative Status: The Role of Acetaldehyde. Alcohol. Clin. Exp. Res. 2019, 43, 1672-1681. [CrossRef] [PubMed]

55. Quertemont, E.; Grant, K.; Correa, M.; Arizzi, M.N.; Salamone, J.D.; Tambour, S.; Aragon, C.M.G.; McBride, W.J.; Rodd, Z.; Goldstein, A.; et al. The Role of Acetaldehyde in the Central Effects of Ethanol. Alcohol. Clin. Exp. Res. 2005, 29, 221-234. [CrossRef] [PubMed]

56. Aragon, C.; Amit, Z. Differences in ethanol-induced behaviors in normal and acatalasemic mice: Systematic examination using a biobehavioral approach. Pharmacol. Biochem. Behav. 1993, 44, 547-554. [CrossRef]

57. Arizzi-LaFrance, M.N.; Correa, M.; Aragon, C.M.G.; Salamone, J.D. Motor Stimulant Effects of Ethanol Injected into the Substantia Nigra Pars Reticulata: Importance of Catalase-Mediated Metabolism and the Role of Acetaldehyde. Neuropsycho-Pharmacology 2006, 31, 997-1008. [CrossRef] [PubMed]

58. Tarragon, E.; Baliño, P.; Aragón, C.M.G.; Tarragon, E. Centrally formed acetaldehyde mediates ethanol-induced brain PKA activation. Neurosci. Lett. 2014, 580, 68-73. [CrossRef] [PubMed]

59. Tsuru-Aoyagi, K.; Potts, M.B.; Trivedi, A.; Bs, T.P.; Raber, J.; Wendland, M.; Bs, C.P.C.; Koh, S.-E.; Ferriero, D.; Noble-Haeusslein, L.J.; et al. Glutathione peroxidase activity modulates recovery in the injured immature brain. Ann. Neurol. 2009, 65, 540-549. [CrossRef]

60. Sánchez-Vallejo, V.; Benlloch-Navarro, S.; Trachsel-Moncho, L.; López-Pedrajas, R.; Almansa, I.; Romero, F.J.; Miranda, M. Alterations in glutamate cysteine ligase content in the retina of two retinitis pigmentosa animal models. Free Radic. Biol. Med. 2016, 96, 245-254. [CrossRef]

61. Kane, C.J.M.; Chang, J.Y.; Roberson, P.K.; Garg, T.K.; Han, L. Ethanol exposure of neonatal rats does not increase biomarkers of oxidative stress in isolated cerebellar granule neurons. Alcohol 2008, 42, 29-36. [CrossRef]

62. Sommavilla, M.; Sánchez-Villarejo, M.V.; Almansa, I.; Sánchez-Vallejo, V.; Barcia, J.M.; Romero, F.J.; Miranda, M. The effects of acute ethanol exposure and ageing on rat brain glutathione metabolism. Free Radic. Res. 2012, 46, 1076-1081. [CrossRef]

63. Wlodek, L.; Rommelspacher, H. Ethanol-induced changes in the content of thiol compounds and of lipid peroxidation in livers and brains from mice: Protection by thiazolidine derivatives. Alcohol Alcohol. 1994, 29, 649-657. [CrossRef] [PubMed]

64. Ayala, A.; Muñoz, M.F.; Argüelles, S. Lipid Peroxidation: Production, Metabolism, and Signaling Mechanisms of Malondialdehyde and 4-Hydroxy-2-Nonenal. Oxidative Med. Cell. Longev. 2014, 2014, 360438. [CrossRef]

65. Argüelles, S.; Machado, A.; Ayala, A. "In vitro" effect of lipid peroxidation metabolites on elongation factor-2. Biochim. Biophys. Acta 2006, 1760, 445-452. [CrossRef] 
66. Łuczaj, W.; Skrzydlewska, E. DNA damage caused by lipid peroxidation products. Cell. Mol. Biol. Lett. 2003, 8, 391-413. [PubMed]

67. Johnsen-Soriano, S.; Francisco, B.-M.; Miranda, M.; Asensio, S.; Barcia, J.M.; Romá, J.; Monfort, P.; Felipo, V.; Romero, F.J. Ebselen Prevents Chronic Alcohol-Induced Rat Hippocampal Stress and Functional Impairment. Alcohol. Clin. Exp. Res. 2007, 31, 486-492. [CrossRef] [PubMed]

68. Almansa, I.; Barcia, J.M.; López-Pedrajas, R.; Muriach, M.; Miranda, M.; Romero, F.J. Naltrexone Reverses Ethanol-Induced Rat Hippocampal and Serum Oxidative Damage. Oxidative Med. Cell. Longev. 2013, 2013, 296898. [CrossRef] [PubMed]

69. Morris, G.; Anderson, G.; Dean, O.; Berk, M.; Galecki, P.; Martin-Subero, M.; Maes, M. The Glutathione System: A New Drug Target in Neuroimmune Disorders. Mol. Neurobiol. 2014, 50, 1059-1084. [CrossRef]

70. Reed, D.; Babson, J.; Beatty, P.; Brodie, A.; Ellis, W.; Potter, D. High-performance liquid chromatography analysis of nanomole levels of glutathione, glutathione disulfide, and related thiols and disulfides. Anal. Biochem. 1980, 106, 55-62. [CrossRef]

71. Lawrence, R.A.; Parkhill, L.K.; Burk, R.F. Hepatic cytosolic non selenium-dependent glutathione peroxidase activity: Its nature and the effect of selenium deficiency. J. Nutr. 1978, 108, 981-987. [CrossRef]

72. Smith, I.K.; Vierheller, T.L.; Thorne, C.A. Assay of glutathione reductase in crude tissue homogenates using $5,5^{\prime}-$ dithiobis $(2-$ nitrobenzoic acid). Anal. Biochem. 1988, 175, 408-413. [CrossRef]

73. Esterbauer, H.; Eckl, P.; Ortner, A. Possible mutagens derived from lipids and lipid precursors. Mutat. Res. Genet. Toxicol. 1990, 238, 223-233. [CrossRef]

74. Richard, M.J.; Guiraud, P.; Meo, J.; Favier, A. High-performance liquid chromatographic separation of malondialde-hydethiobarbituric acid adduct in biological materials (plasma and human cells) using a commercially available reagent. J. Chromatogr. 1992, 577, 9-18. [CrossRef]

75. Romero, F.J.; Bosch-Morell, F.; Jareño, E.J.; Romero, B.; Marín, N.; Romá, J. Lipid peroxidation products and antioxidants in human disease. Environ. Health Perspect. 1998, 106 (Suppl. 5), 1229-1234. [CrossRef]

76. Bradford, M.M. A rapid and sensitive method for the quantitation of microgram quantities of protein utilizing the principle of protein-Dye binding. Anal. Biochem. 1976, 72, 248-254. [CrossRef] 